\title{
Test Procedures of Mobile Air Cleaning Devices - First Experiences and Results
}

\author{
Christian Friebe*, Ralph Krause, Ralf Heidenreich, Stefan Holfeld, Hanes Rosenbaum, \\ Karsten Hackeschmidt and Rebekka Gruttner \\ Institut für Luft und Kältetechnik gGmbH, 01309 Dresden, Germany
}

\begin{abstract}
The pandemic spread of the SARS-CoV2 viruses is leading to the use of new ventilation concepts in Europe. One of these options is the usage of Mobile Air Cleaning Devices. These are used as an alternative to central HVAC-systems (Heating-, Ventilation- and Air Conditioningsystems) and reduce the load of pathogens in the room. However, there are still no consistent methods for evaluating the performances of such devices. Thatswhy the effect on the pathogens, the benefit to the room, and the influence thereof on the room occupants are nearly unknown.This paper presents the measurements and results of different devices in the range of $500 \mathrm{~m}^{3} / \mathrm{h}$ to $1500 \mathrm{~m}^{3} / \mathrm{h}$ and beyond. Attention is given to the applied methods to define the different characteristics. Specifically, the parameters of volumetric flow rate, electrical power consumption, sound power, separation efficiency, effect on pathogens, room air flow, draught risk, and effects in the room show the need for development.
\end{abstract}

\section{Introduction}

While at the beginning of the pandemic spread of the SARS-CoV2 virus it was assumed that transmission was mainly by smear infection, in the course of 2020 it became evident that the most important method of transmitting were airborne particles. As a result, considerations arose as to how the transmission paths could be prevented by means of ventilation options. Possibilities include the use of existing ventilation systems, window ventilation and the use of mobile air cleaning devices. Fig. 1 depicts a matrix to decide on these ventilation measures.

The use of mobile air cleaning devices promises a reliable method of infection reduction that is independent of ambient climatic conditions and that can be easily installed at the same time. The use of these devices was largely unknown in Europe until the outbreak, while in Asia and on the American continent there were already regulations on how to evaluate these devices. Due to this sudden demand of mobile air cleaning devices, there were many open questions in Europe on how to evaluate the use of these devices, how to prove the effectiveness and which restrictions result from their operation. In the context of these questions, ILK Dresden has developed a method to evaluate the mobile air cleaning devices. This method is based on already existing measurement methods and extends these

* Corresponding author: christian.friebe@ilkdresden.de 
to comfort and acoustic acceptance levels. These measurement methods and results are presented as follows.

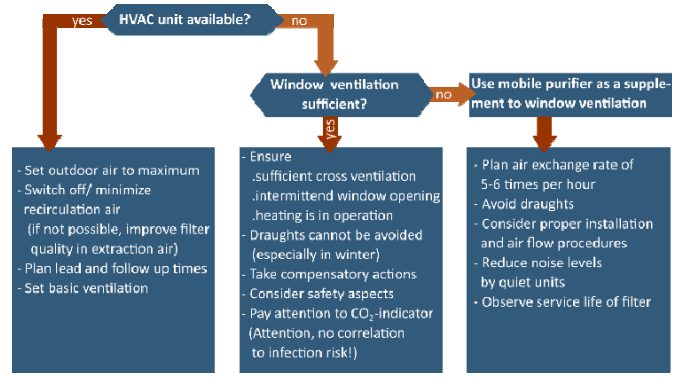

Fig. 1. Matrix to decide on different ventilation measures.

\section{Working principles of mobile air cleaning devices and samples}

Main task of a mobile air cleaning device is the elimination of airborne pollutants. For this purpose, a part of the room air is permanently extracted with a fan, purified and supplied to the room again. The cleaning process can be performed with different methods. These methods are

- Mechanical filtration (H13/H14, ePM1),

- Electrical filtration (EF),

- Ultraviolet radiation (UVC),

- Photocatalytic treatment (PC),

- Ionisation (IO) and

- Combinations of the aforementioned processes.

The reduction of pathogens is characterised by the method-specific percentage of pollutants emitted back into the room in the discharge compared to the amount of pathogens that entered the unit.

The induced air flow in the room represents a mixed flow regime. Additional supply air is optional. The working principle is represented in Fig. 2.

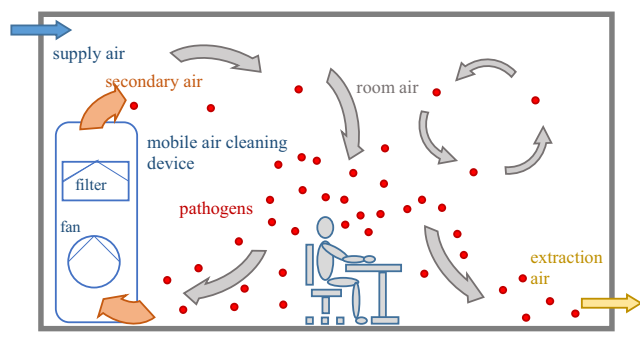

Fig. 2. Mobile air cleaning device and its working principle in a room, in this example with an air flow direction from bottom to the ceiling (BU).

The air flow structures in the room induced by the unit are defined by the unit itself. The units under test can be defined by three different installation methods: 
- from bottom to the ceiling (BU),

- from ceiling to bottom (TD) and

- horizontal (HO).

The measurements in this article were carried out with the mobile air cleaning devices as listed in Table 1.

Table 1. Overview of units under test

\begin{tabular}{|c|c|c|c|c|c|c|}
\hline Unit & Principle & $\begin{array}{c}\text { Direc- } \\
\text { tion }\end{array}$ & $\begin{array}{c}\text { Qnom } \\
\text { SEC/ODA } \\
{\left[\mathbf{m}^{3} / \mathbf{h}\right]}\end{array}$ & $\begin{array}{c}\mathbf{V} \\
{\left[\mathbf{m}^{\mathbf{3}}\right]}\end{array}$ & $W$ & $H$ \\
\hline LR\#001 & $\mathrm{H} 14$ & $\mathrm{BU}$ & $1200 / 0$ & 0.55 & 0.61 & 1.3 \\
\hline LR\#002 & $\mathrm{H} 13$ & $\mathrm{HO}$ & $700 / 0$ & 0.09 & 0.4 & 0.665 \\
\hline LR\#003 & $\mathrm{H} 14$ & $\mathrm{HO}$ & $2500 / 0$ & 0.55 & 0.523 & 1.051 \\
\hline LR\#004 & $\mathrm{H} 13$ & $\mathrm{BU}$ & $1600 / 0$ & 1.04 & 0.644 & 2.313 \\
\hline LR\#005 & $\mathrm{U} 15$ & $\mathrm{TD}$ & $700 / 0$ & 0.28 & 0.6 & 0.39 \\
\hline LR\#006 & $\mathrm{H} 13$ & $\mathrm{BU}$ & $1300 / 0$ & 1.06 & 0.47 & 1.9 \\
\hline LR\#007 & $\mathrm{H} 13$ & $\mathrm{BU}$ & $1800 / 0$ & 1.27 & 1.17 & 1.9 \\
\hline LR\#008 & $\mathrm{EF}$ & $\mathrm{BU}$ & $400 / 0$ & 0.60 & 0.6 & 1.68 \\
\hline LR\#009 & $\mathrm{H} 14$ & $\mathrm{BU}$ & $1350 / 0$ & 0.97 & 0.71 & 1.92 \\
\hline LR\#010 & $\mathrm{UVC}$ & $\mathrm{BU}$ & $700 / 0$ & 0.79 & 0.67 & 1.75 \\
\hline LR\#011 & $\mathrm{UVC}$ & $\mathrm{BU}$ & $1200 / 0$ & 0.78 & 0.3 & 2.18 \\
\hline LR\#012 & $\mathrm{H} 14$ & $\mathrm{TD}$ & $400 / 400$ & 2.30 & 0.675 & 2.0 \\
\hline LR\#013a & $\mathrm{ePM1}$ & $\mathrm{BU}$ & $700 / 0$ & 0.79 & 0.67 & 1.75 \\
& $55 \%+$ & & & & & \\
& $\mathrm{ePM1}$ & & & & & \\
\hline LR\#013b & $\mathrm{H} 13$ & $\mathrm{BU}$ & $700 / 0$ & 0.79 & 0.67 & 1.75 \\
\hline LR\#015 & $\mathrm{H} 14$ & $\mathrm{BU}$ & $1400 / 0$ & 0.63 & 0.6 & 1.75 \\
\hline LR\#016a & $\mathrm{H} 14$ & $\mathrm{BU}$ & $1500 / 0$ & 0.43 & 0.55 & 1.57 \\
\hline LR\#016b & $\mathrm{H} 14$ & $\mathrm{TD}$ & $1300 / 0$ & 0.31 & 0.55 & 1.12 \\
\hline LR\#017 & $\mathrm{H} 14$ & $\mathrm{HO}$ & $1030 / 0$ & 0.22 & 0.505 & 0.655 \\
\hline LR\#020a & $\mathrm{H} 14+\mathrm{UVC}$ & $\mathrm{BU}$ & $2000 / 0$ & 0.68 & 0.53 & 2.19 \\
\hline LR\#020b & $\mathrm{H} 14$ & $\mathrm{BU}$ & $2000 / 0$ & 0.68 & 0.53 & 2.19 \\
\hline LR\#021 & $\mathrm{UVC}$ & $\mathrm{BU}$ & $105 / 0$ & 0.24 & 0.35 & 1.7 \\
\hline LR\#022 & $\mathrm{H} 14$ & $\mathrm{BU}$ & $600 / 0$ & 0.30 & 0.5 & 1.2 \\
\hline & & & & & & \\
\hline
\end{tabular}

\section{Measurement methods}

\subsection{Measurement conditions}

All units were investigated within the same test chamber with a volume of $200 \mathrm{~m}^{3}$. The chamber consists of a concrete wall with smooth surfaces. For the characterisation of the room air flow, the draught rating and the recovery test a suspended ceiling parallel to the floor in a height of $2.9 \mathrm{~m}$ was installed in this chamber. The chamber was equipped with an air duct system for $10000 \mathrm{~m}^{3} / \mathrm{h}$. Nevertheless, all units were investigated in recirculationair mode only.

\subsection{Sound power level}


The measurements to determine the sound power level were carried out in the reverberation chamber of the ILK Dresden, see Fig. 3 a.). It fulfils the criteria of DIN EN ISO 3741 [1]. The following technical parameters essentially characterise the reverberation chamber:

- Third-octave band measurements with centre frequencies $100 \mathrm{~Hz} \ldots 10 \mathrm{kHz}$,

- Volume: $207 \mathrm{~m}^{3}$, surface: $211 \mathrm{~m}^{2}$, mass: $170 \mathrm{t}$

- Vibration-isolated mounted on eight steel spring packs type GP-8.4-2513/47K (Fa.Gerb), eigenfrequency $\mathrm{f} 0=3.4 \mathrm{~Hz}$,

- integrated vibration-insulated basement with an area of $1 \times 2 \mathrm{~m}^{2}$
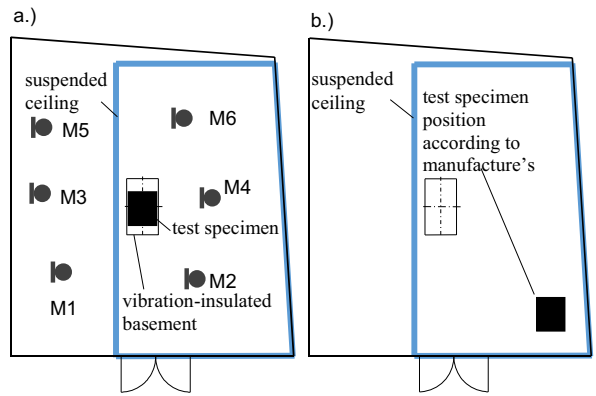

Fig. 3. Measurement setup in the test chamber a.) reverberation room setup for the sound power level measurement, $\mathrm{M}$ indicates the microphones, b.) setup for the remaining measurements.

The sound power level measurement equipment comprises

- the frequency analyser (Sinus Messtechnik GmbH, Soundbook Expander 8L),

- the measuring software (Samurai) and

- six condenser microphones (Microtech Gefell).

The sound power level was calculated by means of the sound pressure detected by the microphones and acoustic characteristics of the reverberation chamber.

\subsection{Volumetric flow rate and electrical power consumption}

Due to the different unit shapes, the volume flow was calculated with a significantly high and uniformly distributed number of single velocity measurements at the inlet of the unit in accordance with DIN EN 12599 [2]. The volumetric flow rate Q is the product of the average air velocity and the area covered by the normal of the discrete velocity vectors.

The units were operated at least in the standard operating mode and in additional modes, if required. They were placed in a position within the chamber according to the manufacturer's instructions. A typical setup is illustrated in Fig. 3 b.).

\subsection{Separation efficiency}

Currently, there is no standard available to test mobile air cleaning devices in terms of air cleaning efficiency. Technologies using high efficient filters could be tested according to the standards for cleanroom equipment to determine the separation efficiency. Based on the fact that the protection of humans is in focus, the test standard DIN EN 13274-7 [3] for testing FFP masks was applied to the testing of mobile air cleaning devices. In the implemented test procedure, a specified paraffin-oil aerosol was injected in the upstream side of the unit. An optical particle counter Lasair III 110 (PMS Germany GmbH) measured 
the particle concentration at the downstream side. To calculate the upstream particle concentration, knowledge of the particle production rate of the aerosol generator ATM 228 (Topas $\mathrm{GmbH}$ ) and the air flow of the air cleaning device is compulsory. The particle production rate was determined in a separate test rig. Based upon the determined upstream and downstream concentration the separation efficiency was calculated for all particle size channels of the particle counter used. The measurement results for particle sizes with a mean diameter of 50 to $200 \mathrm{~nm}$ are presented in section 4 . These diameters correspond to the known sizes of coronaviruses [4].

\subsection{Inactivation efficiency}

Some mobile air cleaning devices were not equipped with a mechanical filtration technology. These devices used chemical or physical effects such like heat, chemical inactivation, UV light or gamma irradiation to inactivate the activity of pathogens. In this particular case, the test routine according to section 3.4 is not appropriate to provide information upon the protection efficiency of these devices. To obtain this data, the units have to be tested with pathogens directly. The inactivation efficiency measurement was performed in collaboration with the University of Leipzig using Feline Coronavirus (FCoV) which is not pathogenic to humans. The air cleaning devices were installed in a test rig that comprises the injection of a suitable virus suspension into the raw-gas and the sampling of viruses in the raw-gas and clean-gas flow (see Fig. 4). The exact determination of the inactivation efficiency was performed by successive reduction of the infectious virus titer in laboratory examinations. To validate these test routines, air cleaning devices with built-in HEPA filters were also tested with both test routines, the inactivation efficiency according to this section and the separation efficiency according to section 3.4.

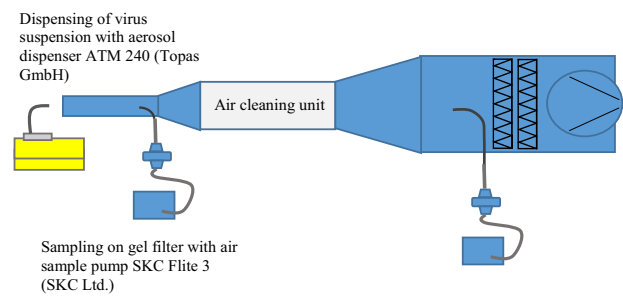

Fig. 4. Test equipment to determine the inactivation efficiency of mobile air cleaning devices.

\subsection{Recovery Test}

In addition to the unit-specific parameters "separation efficiency" (section 3.4) or "inactivation efficiency" (section 3.5) the benefit of the unit to the room is of interest. Therefore a recovery test was performed, that provides information about the air purification performance of the air cleaning unit in a room with defined dimensions. The room with the characteristics according to section 3.1 and Fig. 3 b.) was used. The test room was contaminated first with a glycol test aerosol up to a concentration about 106 particle/ $\mathrm{cm} 3$. After the conditions in the test room had stabilised, the air cleaning device was put into operation and the particle concentration was monitored with an optical particle counter to obtain the recovery curve. Fig. 5 depicts such a typical recovery curve. 


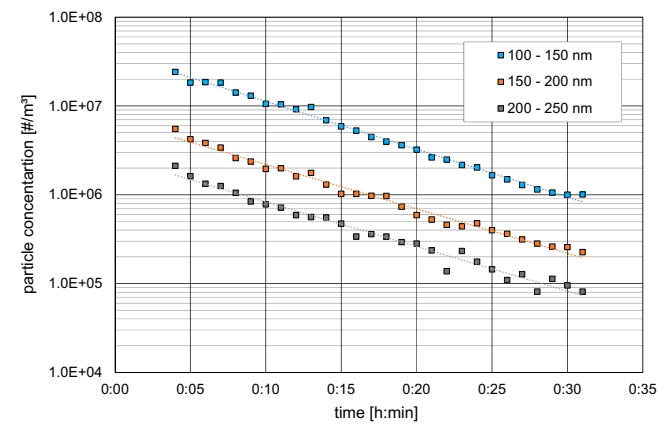

Fig. 5. Typical recovery curve of the particle concentration shown for three different ranges of particle diameters.

With respect to the size of the corona virus and the counting efficiencies of optical particle counter, the particle size range from 150 to $200 \mathrm{~nm}$ was considered for the calculation of the recovery rate. According to the standard VDI 2083-3 [5] and ISO 14644$3[6]$ the results are shown by the ratio of the particle concentration at two different time steps. The recovery rate was calculated by the ratio of the concentration difference at two different times and the time difference itself. Two different measurements were carried out. The first measurement without and the second with air purifier in operation. In this way, the natural decay rate was taken into account as an offset to the device measurement.

\subsection{Room air flow visualisation}

The room air flow was visualised by means of a nebulised liquid. Depending on the working principle of the unit, the aerosols were dosed directly into the outlet $(\mathrm{H} 13 / \mathrm{H} 14$, ePM1) or into the suction side of the unit (remaining working principles). The timedependent distribution of the particles was recorded in a video. The visualisation was carried out in two steps. In the first step, the volumetric distribution of the particles in the room was recorded. For this purpose, a volumetric illumination of the particles was applied, which allows a 3-dimensional observation. In a second step, the particles were illuminated with a laser light sheet. By the application of this light sheet, small flow patterns in one plane, such as recirculation and induction, can be observed. The fog generators Profi 195

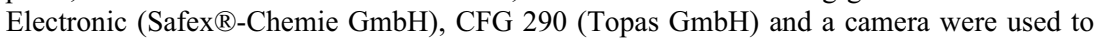
visualise the room air flow. The laser light sheet generator comprises a laser $(200 \mathrm{~W}$, continuous wave, $532 \mathrm{~nm}$ wavelength), a mirror and a motor that rotates the mirror in an axis with adjustable speed.

\subsection{Draught rating}

The tests for the draught ratings were performed according to the DIN EN ISO 7730 [7]. 

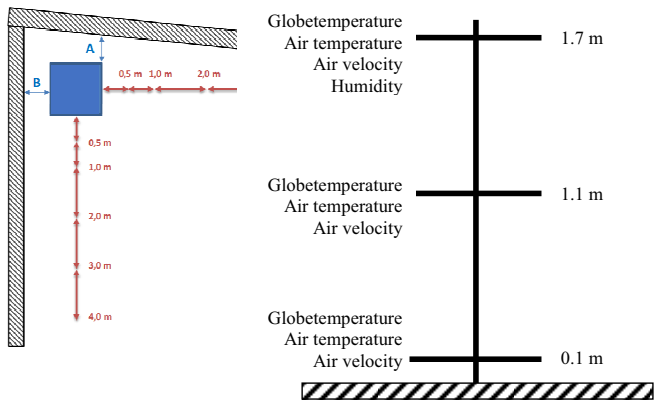

Fig. 6. Draught risk measurement setup.

The measurement system "Draught Rating" comprises

- Temperature probes PT 100, thermally separated probe and housing $\pm 0.15 \mathrm{~K}$

- Air velocity, omnidirectional, temperature compensated $0 \ldots 2 \mathrm{~m} / \mathrm{s}, \pm 0.04 \mathrm{~m} / \mathrm{s}$

- Globe temperature probes PT 100

- Humidity probes HMP110 (Vaisala)

\section{Measurement results and comparison}

For better comparability of the different units, the volume flow of the units was converted to a unit-specific volume flow. This specific flow rate results from the ratio of air volume flow and the volume of the device. The measured results are related to this value in the following. Every value is depicted subsequently in two figures representing the parameters "working principle" and "flow direction".

The specific fan power (SFP) provides information on the power consumption of a fan moving one cubic meter of air within one hour through the unit. Thereof, SFP is calculated by the ratio of the electrical power of the units in $\mathrm{W}$ and the volume flow rate in $\mathrm{m}^{3} \mathrm{~h}-1$. Fig. 7 depicts the results of the SFP for all units under test.

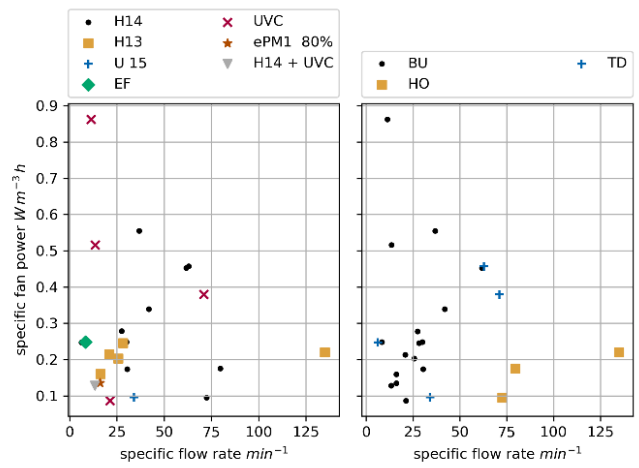

Fig. 7. Specific fan power vs. specific flow rate with filtration principle and flow direction as parameter. 
Fig. 8 illustrates the relation between the sound power level and the specific flow rate. Here, the specific sound power level is used to neglect different unit sizes. The specific sound power level is calculated by the measured sound power level minus the factor 10 of logarithmic value of the clean air delivery rate (CADR). The CADR is the product of the volume flow in $\mathrm{m}^{3} \mathrm{~s}-1$ and the measured filter efficiency.

Beside the acoustic impact upon the user of a room the draught rating is the second import comfort-related aspect. Fig. 9 depicts the results of the draught rating measurements according to section 3.8. Draught ratings of $20 \%$ and more should be considered unacceptable.

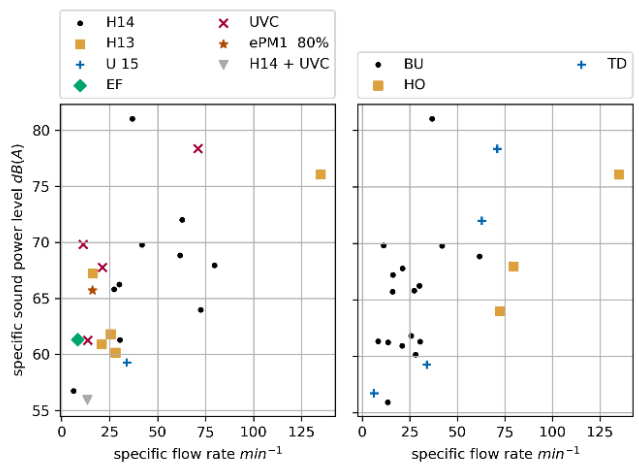

Fig. 8. Specific sound power level vs. specific flow rate with filtration principle and flow direction as parameter.

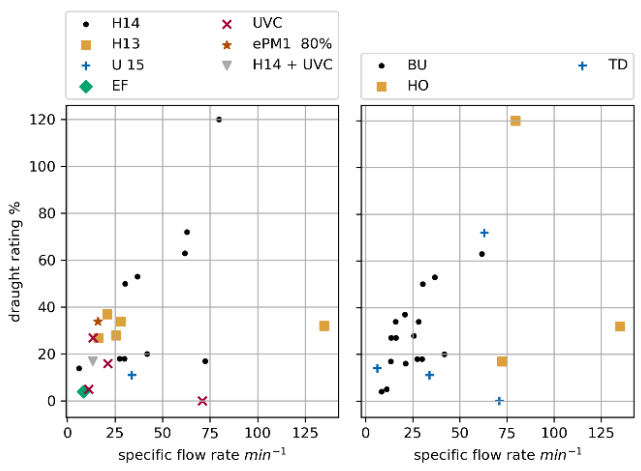

Fig. 9. Draught rating vs. specific flow rate with filtration principle and flow direction as parameter.

Another interesting aspect is the inactivation rate vs the specific flow rate. This relationship is illustrated in Fig. 10. In this context the inactivation rate comprises both, the separation efficiency of mechanical filters and the inactivation rate of units with physical working principles. For a better readability in logarithmic scales, the inactivation rate is presented as the pass-through rate. The higher the value in this diagram, the lower the inactivation rate. 
The capability of reducing the particle concentration in a room by means of a mobile air cleaning device illustrates Fig. 11. The volume flows of the units were standardised to a volume flow that fulfils an air change rate of $6 \mathrm{~h}-1$ in a room of $200 \mathrm{~m}^{3}$.
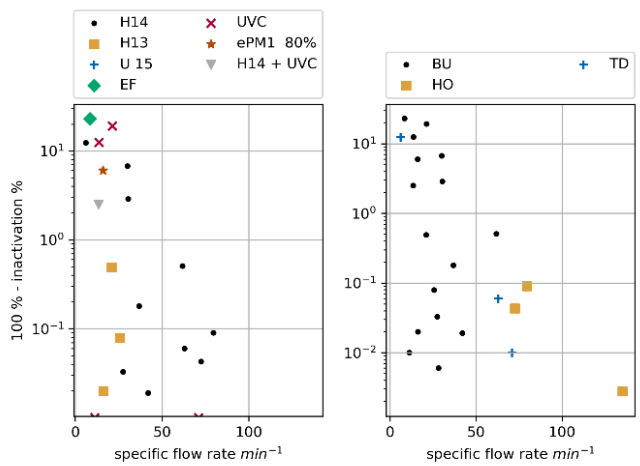

Fig. 10. Pass-through-rate vs. specific flow rate with filtration principle and flow direction as parameter.

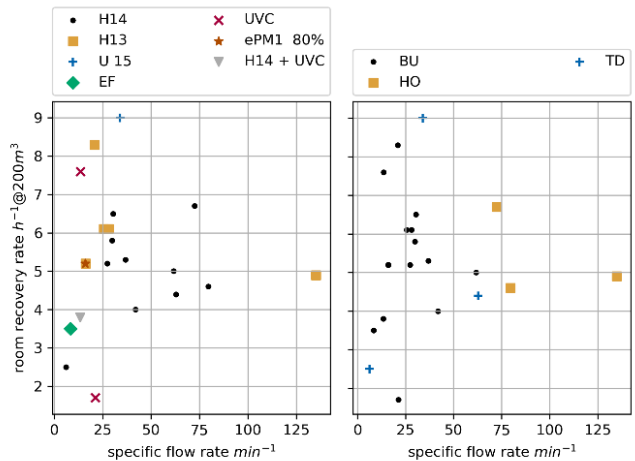

Fig. 11. Recovery rate for a room of $200 \mathrm{~m}^{3}$ and $6 \mathrm{~h}-1$ vs. specific flow rate with filtration principle and flow direction as parameter.

\section{CONCLUSIONS}

In general, the sound power level is too high at the required volume flow rate for continuous use, whilst the draught rating exceeds more than $20 \%$ for several units, which will cause uncomfortable sensations. There is a weak direct correlation between specific sound power level and specific flow rate and a modest indirect correlation with the inactivation rate but no correlation between specific flow rate and draught risk. Furthermore, the specific fan power and the recovery rate are independent of the specific flow rate.

To validate the measurements, devices comprising both mechanical filtration and physical inactivation were measured by particle reduction and virus reduction according to 
section 3.4 and section 3.5, respectively. The results of these measurements were found to be consistent.

The recovery test procedure was found to be appropriate for air cleaning devices with mechanical filtration technology.

In conclusion to the results, the described measurement methods have proven to be reliable and feasible. Nonetheless, there is still a great potential for research to develop standardised test and qualification procedures for mobile air cleaning devices:

- A recovery test method for devices with other technologies to inactivate pathogens than mechanical filtration.

- A recovery test method with multi-point measurement method for particle concentration but without expanding the amount of particle counters.

- Investigations regarding the fluid-mechanical interaction between the room and the unit, in particular the transferability of the flow conditions in the test room to the actual setup of the unit.

- The development of units with low noise emission and high recovery rate at low specific fan power is urgently required.

As a side note, some units were identified with a lower filter class than specified. The underlying reason was leakage.

\section{References}

[1] DIN EN ISO 3741 2011-01: Akustik - Bestimmung der Schallleistungs- und Schallenergiepegel von Geräuschquellen aus Schalldruckmessungen - Hallraumverfahren der Genauigkeitsklasse 1 (ISO 3741:2010); Deutsche Fassung EN ISO 3741:2010 : Deutsches Institut für Normung, 2011

[2] DIN EN 12599:2013-01 Lüftung von Gebäuden - Prüf- und Messverfahren für die Übergabe raumlufttechnischer Anlagen; Deutsche Fassung EN 12599:2012 : Deutsches Institut für Normung, 2013

[3] DIN EN 13274-7 2019-09: Atemschutzgeräte - Prüfverfahren - Teil 7: Bestimmung des Durchlasses von Partikelfiltern; Deutsche Fassung : Deutsches Institut für Normung, 2019

[4] CHEN, NANSHAN ; ZHOU, MIN ; DONG, XUAN ; QU, JIEMING ; GONG, FENGYUN ; HAN, YANG ; QIU, YANG ; WANG, JINGLI ; LIU, YING ; ET AL.: Epidemiological and clinical characteristics of 99 cases of 2019 novel coronavirus pneumonia in Wuhan, China: a descriptive study. In: The Lancet vol. 395 (2020), Nr. 10223, pp. 507-513

[5] VDI 2083 Blatt 3 2005-07: Reinraumtechnik - Messtechnik in der Reinraumluft : VDI, 2005

[6] DIN EN ISO 14644-3 2020-08: Reinräume und zugehörige Reinraumbereiche - Teil 3: Prüfverfahren (ISO 14644-3:2019, korrigierte Fassung 2020-06); Deutsche Fassung EN ISO 14644-3:201 : Deutsches Institut für Normung, 2020

[7] DIN EN ISO 7730 2006-05: Ergonomie der thermischen Umgebung - Analytische Bestimmung und Interpretation der thermischen Behaglichkeit durch Berechnung des PMV- und des PPD-Indexes und Kriterien der lokalen thermischen Behaglichkeit (ISO 7730:2005); Deutsche Fassung EN ISO 7730:2005 : Deutsches Institut für Normung, 2006 